\title{
Productivity Growth and Capital Flows: The Dynamics of Reforms
}

\author{
Francisco J. Buera* Yongseok Shin ${ }^{\dagger}$
}

August 8, 2009

\begin{abstract}
Why doesn't capital flow into fast-growing countries? In this paper, we provide a quantitative framework incorporating heterogeneous producers and underdeveloped domestic financial markets to study the joint dynamics of total factor productivity (TFP) and capital flows. When an unexpected once-and-for-all reform eliminates non-financial distortions and liberalizes capital flows, the TFP of our model economy rises gradually and capital flows out of it. The rise in TFP reflects efficient reallocation of capital and talent, a process drawn out by frictions in domestic financial markets. The concurrent capital outflows are driven by the positive response of domestic saving to higher returns, and by the sluggish response of domestic investment to the higher TFP - the latter being another ramification of domestic financial frictions. We use our model to analyze the welfare consequences of opening up capital accounts. We find that the marginal welfare effect of capital account liberalization is negative for workers and positive for entrepreneurs and wealthy individuals.
\end{abstract}

Keywords: Capital flows; Productivity growth; Financial frictions

\footnotetext{
${ }^{*}$ Department of Economics, University of California at Los Angeles and NBER; fjbuera@econ.ucla.edu.

${ }^{\dagger}$ Department of Economics, Washington University in St. Louis and Federal Reserve Bank of St. Louis; yshin@wustl.edu.
} 
The standard economic theory suggests that capital should flow from rich to poor countries, unless the poor countries have lower overall productivity (Lucas, 1990) or a higher relative cost of investment (Caselli and Feyrer, 2007). Another prediction of the standard theory, arguably less controversial, is that capital should flow into countries experiencing a sustained increase in total factor productivity (TFP). The evidence from developing countries over the last three decades contradicts this prediction. If anything, capital tends to flow out of countries with fast-growing productivity, and into those with poorer performance (Prasad et al., 2007; Gourinchas and Jeanne, 2007).

From the time-series data of capital flows and TFP, we observe that many episodes of sustained TFP growth follow large-scale reforms and economic liberalizations. The periods of increasing net foreign asset positions (capital outflows) coincide with such episodes. A successful explanation of these phenomena requires both a theory of TFP dynamics and a model of international factor reallocation. This is the goal of our paper.

We develop a quantitative framework where economy-wide growth-enhancing reforms and liberalizations lead to a sustained period of productivity growth and capital outflows. We then use the model to evaluate the welfare consequences of capital account liberalization.

We study the transitional dynamics of open economies with heterogeneous producers and imperfect domestic financial markets. In our model, a reform initiates reallocation of resources from previously-subsidized producers to productive entrepreneurs who have not been subsidized before and are hence relatively poor. Such reallocation drives up aggregate TFP. The reallocation is gradual because of the frictions in the domestic financial market. In the early stages of the post-reform transition, the problem for this economy is misallocation of capital, not under-accumulation. With demand for capital restricted by the poorly-functioning domestic financial market, the surplus capital goes overseas in search of a higher return.

Heterogeneous production units and imperfect financial markets are important elements of endogenous TFP dynamics (Buera and Shin, 2008). We model financial frictions in the form of collateral constraints founded on imperfect enforceability of contracts. We consider economies where, in addition to financial frictions, individual entrepreneurs are subject to idiosyncratic distortions, e.g., idiosyncratic taxes/subsidies, and sector-specific or size-dependent policies/regulations. Such distortions help explain resource misallocation and resulting low aggregate productivity levels in less developed economies (Hopenhayn and Rogerson, 1993; Lagos, 2006; Restuccia and Rogerson, 2008; Guner et al., 2008; Hsieh and Klenow, 2007).

There are three kinds of reforms that we consider for our model economies: (i) a reform that addresses idiosyncratic distortions; (ii) trade and capital account liberalization; (iii) a reform of domestic financial institutions.

In our main exercises, we consider two different sequencing of reforms. These exercises start with the same initial condition. We construct this initial condition by computing a stationary equilibrium of an economy that (i) has idiosyncratic distortions, (ii) is closed to goods and capital flows, and (iii) has poorly-functioning domestic financial markets. 
In our first exercise, starting from this initial condition, we implement a reform that eliminates the idiosyncratic non-financial distortions that interfere with efficient allocation of factors across entrepreneurs. At the same time, we liberalize the goods and capital flows in and out of this economy. We assume that domestic financial frictions remain as before. We think of financial frictions as arising from imperfect enforceability of contracts, which is a component of broader institutions and hence more sluggish. This sequencing of reforms - removing idiosyncratic distortions and opening up to international capital markets, while not reforming the domestic financial institutions - reflects the actual experiences during the 1980s of Chile, India, Israel, Korea, Mauritius, and Taiwan. For these countries, domestic financial markets remained relatively underdeveloped until the late 1990s. In our model, the elimination of idiosyncratic distortions leads to a sustained growth in productivity. TFP rises because the removal of idiosyncratic distortions leads to efficient reallocation of resources. The rise is gradual and persistent because the underdeveloped domestic financial markets can reallocate capital only slowly over time. Productive-but-poor individuals have to work for wage for a while before they can save up enough collateral and enter into entrepreneurship. In addition, even after they start their business, it takes time for them to overcome the credit constraints and operate at the maximal-profit scale.

More important, capital flows out of this economy immediately following the reform. Intuitively, in a closed economy with financial frictions, the equilibrium interest rate is lower than in an economy with well-functioning financial markets: Credit frictions restrict the demand for capital by constrained entrepreneurs, and they also induce constrained entrepreneurs to accumulate more assets for self-financing purposes (more supply of capital). When capital flows are liberalized and this small, now-open economy takes as given the world interest rate, there is an excess supply of capital at the new and higher rental rate of capital. The surplus capital gets employed overseas.

Capital flows mirror the difference between saving by domestic residents and domestic investment. Along the transition, domestic residents increase their saving in response to the higher interest rate, eventually arriving at a stationary equilibrium with larger average asset holdings. The removal of idiosyncratic distortions also affects entrepreneurs' investment and saving decisions. Following the reform, the demand for capital from domestic production units falls further, as the previously-subsidized entrepreneurs either exit or curtail their production, while the nowproductive individuals cannot enter and operate at an efficient scale promptly because of the collateral constraints. As the productive entrepreneurs enter and increase their scales of operation over time, domestic demand for capital goes up. However, this increased demand is partly offset by accumulation of assets (supply of capital) by these entrepreneurs for self-financing purposes, and capital does not flow back into this economy. In summary, the central economic force behind the capital outflows in this exercise is the increase in domestic residents' saving which outstrips the changes in domestic investment.

In our second exercise, we reform the domestic financial institutions as a part of a broader reform package that also eliminates idiosyncratic distortions and liberalizes capital accounts. This is a reasonable description of an economy that implements an across-the-board reform. The drastic 
reforms of Estonia in the early 1990s are an representative example.

In this exercise, TFP increases for two reasons: the removal of idiosyncratic distortions, and the improved financial markets. Unlike in the first exercise, as we eliminate idiosyncratic distortions and open up the economy, capital flows into this economy. This outcome arises because the domestic financial market in this reformed economy functions better than that in the first exercise: The reallocation of capital among heterogeneous producers is expedited, and productive individuals can enter entrepreneurship and expand their operation more quickly. As a result, the TFP grows much faster than in the first exercise. More to the point, domestic capital demand rises immediately after the reform, and capital flows in from overseas to meet this excess demand.

It is informative to compare the second exercise with one using the standard neoclassical growth model. In our setup, an economy with perfect domestic credit markets is isomorphic to the neoclassical growth model. If the productivity of the aggregate production function is raised in the neoclassical model, capital will flow into this small open economy and equalize the return to capital with the world level instantaneously. Although our domestic financial market reform does not take our economy all the way to the perfect-credit benchmark, we obtain results that are qualitatively similar.

In both exercises, the reforms simultaneously implemented the removal of idiosyncratic distortions and the opening up of capital accounts. To understand why we model the reforms this way, consider the following. One possibility is for the country to open up the capital account without removing idiosyncratic distortions. As is discussed above, capital will still flow out of this country, because at the new, higher interest rate there is excess supply of capital in the domestic rental market. However, TFP will remain largely unchanged, and we will not be able to address the observed co-movements of TFP and capital flows. Another possibility is to implement a reform to eliminate idiosyncratic distortions while remaining a closed economy. The TFP will increase over time as resources are reallocated, but by assumption we will not observe any capital flows. As our goal is to study the joint dynamics of TFP and capital flows, we need to consider an exercise where we eliminate idiosyncratic distortions and open up the economy.

Given the different results we obtain in the first and the second exercises, it is natural to ask which sequencing of reforms is a more accurate description of emerging economies' experiences. There is ample documentation showing the prevalence of the sequencing in our first experiment: Reduction of sector-specific or size-dependent taxes and subsidies, along with capital account liberalizations, preceded reforms of domestic financial institutions in the countries that are relevant for our analysis. In fact, the first two are often referred to as "first-generation" reforms, while domestic financial institutions belong to the domain of "second-generation" reforms (Camdessus, 1999). After all, the reform of domestic financial institutions in emerging economies surfaced onto the center stage of international policy debate only after the East Asian and Russian financial crises of the late 1990s (Mishkin, 2003; Stulz, 2005; Kaminsky and Schmukler, 2008).

Our model lends itself well to a quantitative welfare analysis. Of particular interest is the welfare consequence of capital account liberalization. Given that economists agree on the desirability of 
removing idiosyncratic distortions, we ask whether it is better to open up to international capital flows at the same time or not. Comparing the results of our first exercise (removal of idiosyncratic distortions while opening up) and the other case where these distortions are eliminated while the economy remains closed, we find that not all individuals benefit from concurrent capital account liberalization. Obviously, the wealthy directly benefit from capital account liberalization, which instantaneously gives them higher returns - the world interest rate - on their financial assets. Highability individuals, who will choose to be entrepreneurs and tend to become wealthy, are better off when the economy opens up. On the other hand, low-ability individuals, who will choose to be workers, are better off when the economy remains closed, unless they start out very wealthy. With capital account liberalization, capital flows out of the country following the reform. Holding other things equal, this implies less capital per worker for domestic production, and the wage is lower than in the closed-economy transition, albeit temporarily. Wage eventually rises to a higher level with capital account liberalization, but the lower wage along the transition prevails on the overall welfare of low-ability individuals.

We draw the following conclusions from our exercises. To assess the effects of the liberalizations of cross-border capital flows, it is important to first understand their interaction with various distortions that interfere with the allocation of production factors within an economy. It is also important to understand the scope and sequencing of reforms that will be undertaken with the capital account liberalization. The rest of this paper is an attempt at a quantitative exploration of this mechanism.

Related Literature The earlier literature on capital flows into developing countries focused on the Lucas puzzle - the small size of capital flows from rich to poor countries. Gertler and Rogoff (1990) and Boyd and Smith (1997) developed theories demonstrating how frictions in domestic capital markets can interact with international capital markets and cause capital to flow from poor to rich countries. Matsuyama (2005) is a more recent example in this context. Caballero et al. (2008) and Mendoza et al. (2009) emphasize this interaction between domestic and international financial markets to explain "global imbalances," using models where the primary function of financial markets is to facilitate consumption smoothing. Castro et al. (2004) also analyze how domestic financial market imperfections can influence the direction of international capital flows.

More recently, it has been documented that capital tends to flow out of fast-growing (in terms of output) countries, and into those with below-average growth (Prasad et al., 2007). Carroll et al. (2000) use habit formation in preferences to explain this phenomenon in an endowment-economy setup. On the other hand, Sandri (2009) and Song et al. (2009) use production-economy models to explain the best-known example of a country that has grown fast and amassed a huge amount of foreign assets during the past decade and a half: China. Sandri (2009) focuses on the market incompleteness in sharing entrepreneurial risk, and in this sense is closely related to the underlying mechanism of Caballero et al. (2008) and Mendoza et al. (2009). Song et al. (2009) capture the interaction between the private sector and the state-owned firms with privileged access to financing, 
a salient feature of the Chinese economy.

What sets our paper apart from the rest is our emphasis on endogenizing the joint dynamics of capital flows and TFP growth to directly address the "allocation puzzle" documented by Gourinchas and Jeanne (2007): Among developing countries, those countries whose productivity increased relative to the rest of the world exported capital. ${ }^{1}$ Another distinction of our paper is that we build a quantitatively-oriented model, so that we can quantify the effect of underlying mechanisms. Also, unlike many earlier models that use a two-period overlapping-generation structure, ours has an yearly frequency, which is important given the window of about ten years that we are interested in. $^{2}$

Our work also relates to the recent papers by Aoki et al. (2007, 2009), who study theoretically how the adjustment to liberalization of international financial transactions depends upon the degree of domestic financial development. We develop a quantitatively-oriented model to study the joint dynamics of capital flows and TFP growth following a broader set of reforms. ${ }^{3}$ In our framework, the liberalization of capital flows unaccompanied by other reforms only generates inconsequential TFP dynamics. In order to account for the joint dynamics of capital flows and TFP growth, one needs to consider the broader set of reforms implemented in many developing economies.

\section{Empirical Motivation: Allocation Puzzle}

In this section we review the evidence on capital flows and productivity growth. First, we reproduce the findings of Gourinchas and Jeanne (2007) for the 1980-1995 period: Countries that exhibit large TFP growth tend to increase their net foreign asset position. We then explore in more detail the time series of TFP and net foreign asset positions for six countries that implemented large-scale economic reforms and liberalizations in this period: Chile, India, Israel, Korea, Mauritius, and Taiwan. As we show below, the large-scale economic reforms in these countries led to sustained TFP growth accompanied by net accumulation of foreign assets.

Figure 1 illustrates the relationship between the changes in net foreign asset positions and productivity growth. TFP growth is defined as per-capita income growth net of the contribution of physical and human capital. ${ }^{4}$ As is clear from the figure, there is a significant positive relationship between the net accumulation of foreign assets (capital outflows) and TFP growth. On average, one percentage point increase in TFP growth rate translates into 0.3 percentage point increase in the net foreign asset to GDP ratio. Net foreign assets are measured in US dollars. We use

\footnotetext{
${ }^{1}$ Our main mechanism-domestic financial frictions distorting allocation of capital both within and across countries - is a recurring theme in the literature, and in particular it is one of the potential resolutions of the allocation puzzle conjectured by Gourinchas and Jeanne themselves.

${ }^{2}$ With respect to Sandri (2009) and Song et al. (2009) in particular, our paper complements their work as we look at a wider set of countries and also a different time period, 1980-95. Notably, China is not one of the "allocation puzzle" countries during this period. In Section 1, we discuss this issue in more detail.

${ }^{3}$ Compared to Aoki et al. (2007, 2009), our model has richer heterogeneity across entrepreneurs, an extensive margin allowing unproductive entrepreneurs to become workers, and decreasing-returns-to-scale technologies at the level of production units.

${ }^{4}$ We use the series of Bernanke and Gürkaynak (2001) who assume a seven per cent return to schooling.
} 


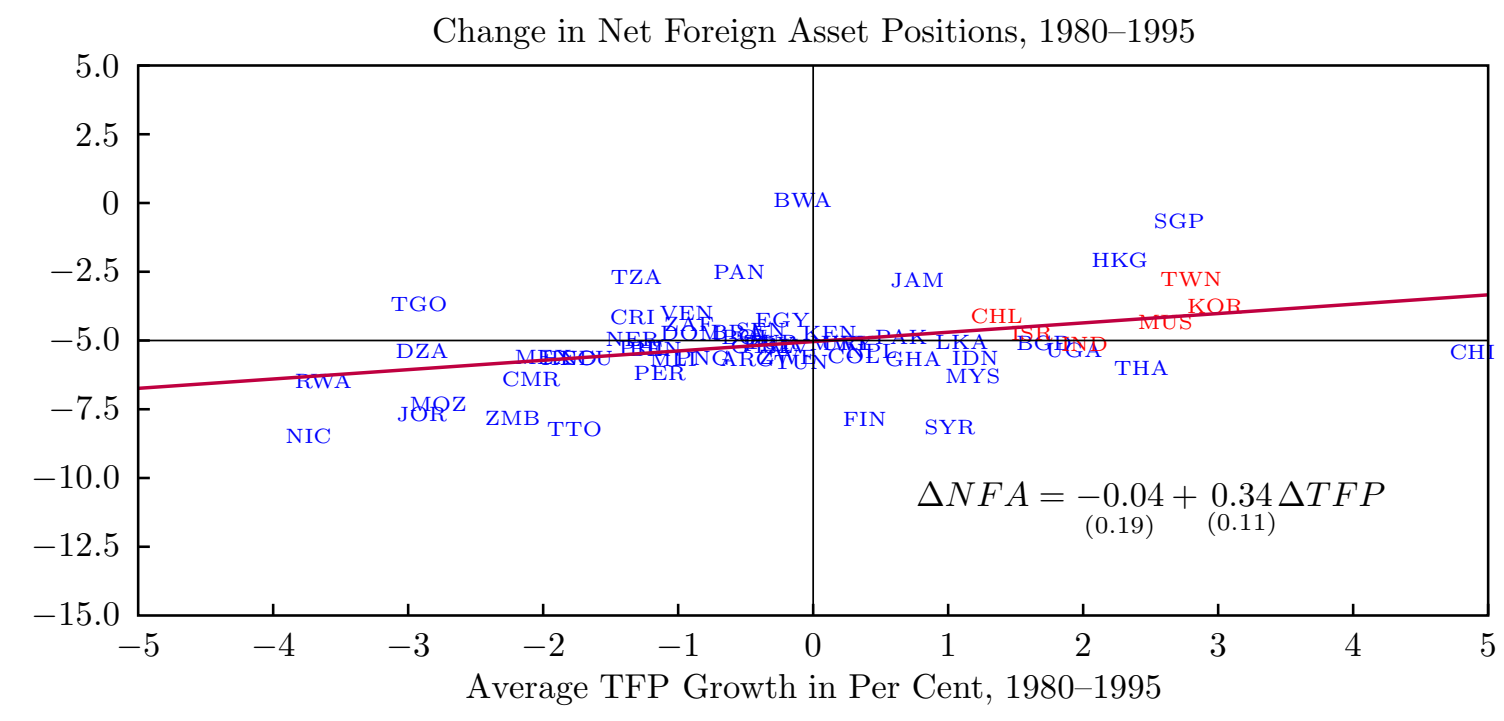

Fig. 1: Allocation Puzzle. The horizontal axis measures the average TFP growth rates over 1980-1995. The vertical axis measures the average rate of change in net foreign asset positions as a fraction of PPP GDP over the same period. Negative (positive) numbers imply capital inflows (outflows). The net foreign asset position data are from Lane and Milesi-Ferretti (2007).

international prices to construct the GDP series. ${ }^{5}$ Another thing to note is that we aggregate the net foreign asset position of a country's public and private sectors. With capital control, most foreign asset transactions are channeled through government agencies, and hence the public vs. private distinction is misleading. For the six countries we discuss below, we consulted their government fiscal balance data and concluded that the movements in national saving are not largely driven by public saving. ${ }^{6}$

We focus on the 1980-1995 period for three reasons. Firstly, the 1980s witnessed the first wave of capital account liberalizations in emerging economies. Secondly, during the 1990s, innovations in international financial markets (e.g. derivatives and off-balance sheet transactions) made it harder to closely keep track of cross-border capital flows, substantially amplifying measurement problems (Lane and Milesi-Ferretti, 2007). Lastly, many emerging economies adopted an explicit policy of improving their net foreign asset positions in the aftermath of the East Asian and Russian financial crises of the late 1990s. We focus on the relationship between productivity and capital flows, and our framework is not designed for an analysis of crises or such post-crisis behavior.

We take a closer look at the countries in the northeast quadrant (productivity growth and capital outflows), and explore the time-series of their TFP and net foreign asset positions. For six of these countries, we can identify and date large-scale economic reforms that coincide with the onset of TFP growth. They are: Chile, India, Israel, Korea, Mauritius, and Taiwan. We do not

\footnotetext{
${ }^{5}$ If one were to use domestic prices to construct the GDP series, the ratio of net foreign asset positions to GDP becomes much more volatile, owing to the fluctuations in the nominal exchange rates. In addition, the slope coefficient becomes 1.02, worsening the allocation puzzle.

${ }^{6}$ The fiscal balance data are from tables in Bosworth et al. (1994), Leipziger (1997), Dommen and Dommen (1999), Dabee and Greenaway (2001), Ben-Bassat (2002), and Kochhar et al. (2006).
} 
consider Hong Kong and Singapore for two reasons. Firstly, unlike the six countries above, we could not clearly date a large-scale reform episode for Hong Kong or Singapore. More important, Hong Kong and Singapore were developing into off-shore banking centers during this period, and hence interpreting their net foreign asset positions is problematic. See Lane and Milesi-Ferretti (2007) for more on this issue. Also note that our sample period precedes the massive acquisition of foreign assets by China (far right side in Figure 1).
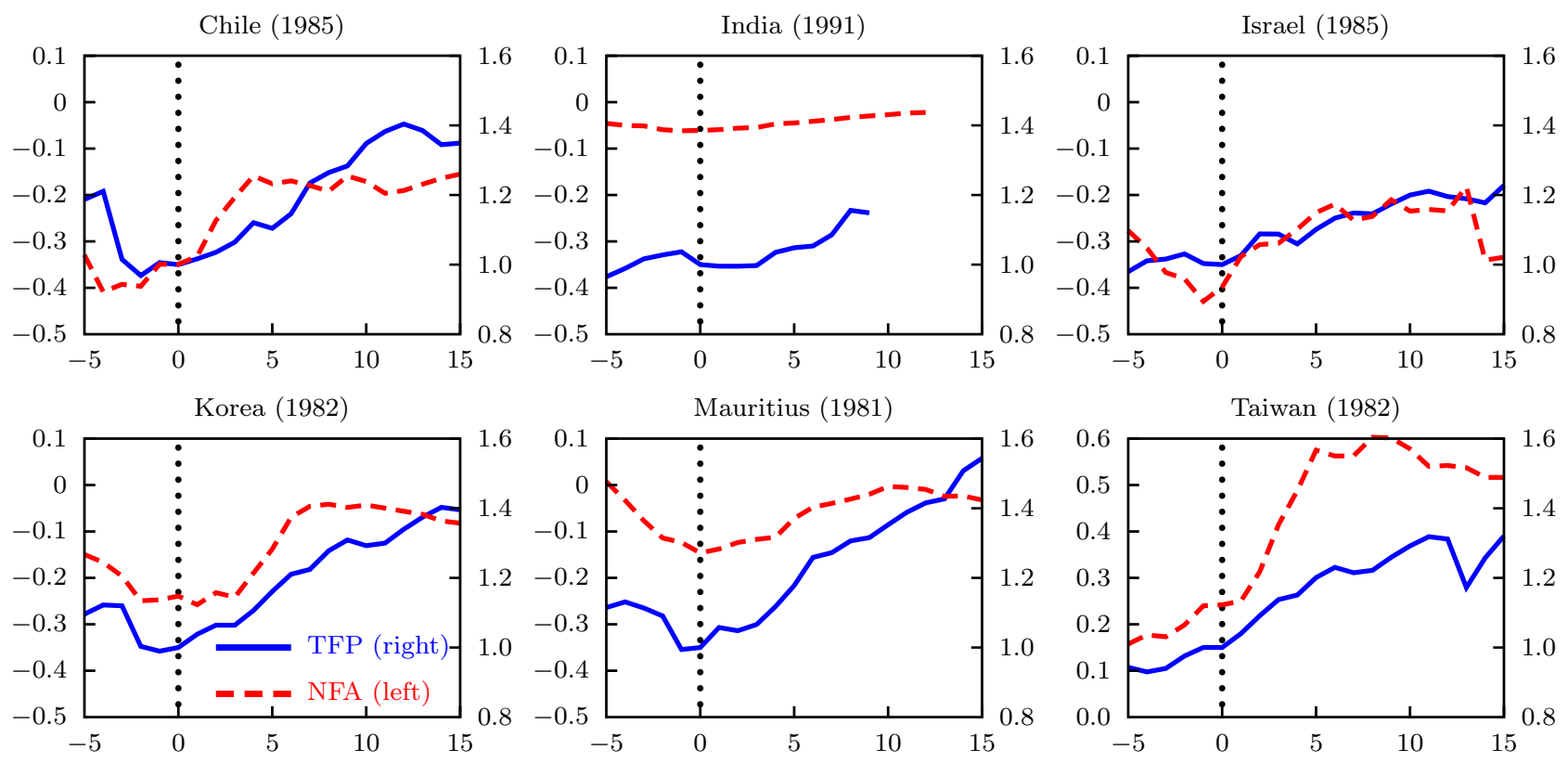

Fig. 2: TFP and Net Foreign Asset Position. Year 0 on the horizontal axis (unit in years) is the year of reform implementation, which is shown in parentheses next to the country name. Net foreign asset position as a fraction of PPP GDP is measured on the left scale, and aggregate TFP can be read off the right scale. TFP is normalized by its value in year 0 .

Figure 2 shows the evolution of net foreign asset positions (dashed lines) and productivity (solid lines) before and after major economic reforms. The year of the reform is set to zero, and the two variables are plotted for the surrounding 20 years. Net foreign asset positions are measured relative to PPP GDP (left scale), and TFP is relative to the year zero level (right scale). The dates of the reforms are 1981 for Mauritius, 1982 for Korea and Taiwan, 1985 for Chile and Israel, and 1991 for India. See the appendix for a description of these reform episodes. In all six cases, these large-scale reforms ushered in a period of sustained productivity growth. At the same time, capital flowed out of these countries. Figure 2 shows that the relationship in Figure 1 is not a result of time aggregation.

\section{Model}

The above empirical observations call for a model of TFP dynamics and capital flows. We propose a model with individual-specific technologies and imperfect credit markets. 
In each period, individuals choose either to operate an individual-specific technology - i.e. to become entrepreneurs, or to work for a wage. This entrepreneur-worker occupation choice allows for endogenous entry and exit in and out of the production sector, which are an important channel of resource allocation. Imperfection in credit markets is modeled with a collateral constraint on capital rental that is proportional to an individual's financial wealth.

Individuals are heterogeneous with respect to their entrepreneurial ability and wealth. Our model generates endogenous dynamics for the joint distribution of ability and wealth. This abilitywealth dynamics will turn out to be crucial for understanding macroeconomic transitions. In addition, heterogeneity in entrepreneurial ability is essential in modeling how resource misallocation leads to lower output and TFP.

We consider both an economy that is closed to capital flows and a small open economy facing a constant world interest rate. However, in this section, we do not consider idiosyncratic (nonfinancial) distortions such as idiosyncratic taxes/subsidies and size-dependent policies. We show how to introduce idiosyncratic distortions into our model in Section 3.1.2.

Heterogeneity and Demographics Individuals live indefinitely, and are heterogeneous with respect to their wealth $a$ and their entrepreneurial ability $e \in \mathcal{E}$, with the former being chosen endogenously by forward-looking saving decisions. An individual's ability follows a stochastic process. In particular, individuals retain their ability from one period to the next with probability $\psi$. With probability $1-\psi$, an individual loses the current ability and has to draw a new entrepreneurial ability. The new draw is from an time-invariant ability distribution, and is independent of one's previous ability level. One can think of the ability shock as an arrival of a new technology making previous production processes obsolete or less profitable. In Section 3.1.1 we will calibrate this shock to be of a relatively low frequency (an average duration of ten years), to match the frequency of establishment turnovers in the US data.

We denote by $\mu(e)$ the measure of type-e individuals in the invariant distribution. We denote by $G_{t}(e, a)$ the cumulative density function for the joint distribution of ability and wealth at the beginning of period $t$. Naturally, $G_{t}(a \mid e)$ is the associated c.d.f. of wealth for a given ability type $e$. The population size of the economy is normalized to one, and there is no population growth.

Preferences Individuals discount their future utility using the same discount factor $\beta$. The preferences over contingent plans for the consumption sequence from the point of view of an individual in period $t$ are represented by the following expected utility:

$$
\mathbb{E}_{t} \sum_{s=t}^{\infty} \beta^{s-t} u\left(c_{s}\right)
$$

Technologies In any given period, individuals can choose either to work for a wage or to operate an individual-specific technology. We label the latter option as entrepreneurship. We assume that an entrepreneur with talent $e$ who uses $k$ units of capital and hires $l$ units of labor produces according 
to a production function $f(e, k, l)$, which is assumed to be strictly increasing in all arguments, and strictly concave in capital and labor, with $f(0, k, l)=0$ and $\lim _{e \rightarrow \infty} f(e, k, l)=\infty$.

Financial Markets Productive capital is the only asset in the economy. There is a perfectlycompetitive financial intermediary that receives deposits, and rents out capital to entrepreneurs. The return on deposited assets - i.e. the interest rate in the economy - is $r_{t}$. The zero-profit condition of the intermediary implies that the rental cost of capital is $r_{t}+\delta$, where $\delta$ is the depreciation rate. If the economy is open to capital flows, its interest rate will be equal to the constant world interest rate $r^{*}$ : The intermediary can accept deposits from foreigners as well as domestic residents at the interest rate $r^{*}$, and rent capital to foreign and domestic entrepreneurs at the world rental rate of capital $r^{*}+\delta$.

We assume that entrepreneurs' capital rental $(k)$ is limited by a collateral constraint $k \leq \lambda a$, where $a$ is individual financial wealth and $\lambda$ measures the degree of credit frictions, with $\lambda=+\infty$ corresponding to perfect credit markets, and $\lambda=1$ to financial autarky where all capital has to be self-financed by entrepreneurs. The same $\lambda$ applies to everyone in a given economy.

Our specification captures the common prediction from models of limited contract enforcement: The amount of credit is limited by individuals' wealth. At the same time, its parsimoniousness enables us to analyze quantitative effects of financial frictions on aggregate transitional dynamics without losing tractability. This specification has been widely used in the literature on financial frictions and entrepreneurship (Evans and Jovanovic, 1989), and also in the literature on credit frictions and business cycles (Bernanke et al., 1999; Kiyotaki and Moore, 1997).

Our collateral constraint can be derived from the following limited enforcement problem. Consider an individual with financial wealth $a$ (deposited in the financial intermediary) at the beginning of a period. Assume that she rents $k$ units of capital. Then she may choose to abscond with a fraction $(1 / \lambda)$ of the rented capital. The only punishment is that she will lose her financial wealth $a$ deposited in the intermediary. In particular, she will not be excluded from any economic activities in the future. In fact, she is allowed to instantaneously deposit the stolen capital $k / \lambda$ and continue on as a worker or an entrepreneur. Note that $\lambda$ in this context measures the degree of capital rental contract enforcement, with $\lambda=+\infty$ corresponding to perfect enforcement and $\lambda=1$ to no enforcement. In the equilibrium, the financial intermediary will rent capital only to the extent that no individual will renege on the rental contract, which implies a collateral constraint $k / \lambda \leq a$ or $k \leq \lambda a$.

It should be noted that we focus on within-period borrowing, or capital rental, for production purposes. We do not allow borrowing for intertemporal consumption smoothing in our model, which translates into $a \geq 0$. This constraint will only bind for individuals who choose to be workers, and has no direct bearing on the behavior of entrepreneurs, who will need to hold assets to overcome the collateral constraint. 
Individuals' Problem The problem of an agent in period $t$ can be written as:

$$
\begin{aligned}
& \max _{\left\{c_{s}, a_{s+1}\right\}_{s=t}^{\infty}} \mathbb{E}_{t} \sum_{s=t}^{\infty} \beta^{s-t} u\left(c_{s}\right) \\
& \text { s.t. } c_{s}+a_{s+1} \leq \max \left\{w_{s}, \pi\left(a_{s} ; e_{s}, w_{s}, r_{s}\right)\right\}+\left(1+r_{s}\right) a_{s}, \forall s \geq t
\end{aligned}
$$

where $e_{t}, a_{t}$, and the sequence of wages and interest rates $\left\{w_{s}, r_{s}\right\}_{s=t}^{\infty}$ are given, and $\pi(a ; e, w, r)$ is the profit from operating an individual technology. This indirect profit function is defined as:

$$
\pi(a ; e, w, r)=\max _{l, k \leq \lambda a}\{f(e, k, l)-w l-(\delta+r) k\}
$$

The input demand functions are denoted by $l(a ; e, w, r)$ and $k(a ; e, w, r)$, and the collateral constraint $(k \leq \lambda a)$ is taken into account.

The max operator in the budget constraint stands for the occupation choice. A type-e individual with current wealth $a$ will choose to be an entrepreneur if profits as an entrepreneur, $\pi(a ; e, w, r)$, exceed labor income as a wage earner, $w$. This occupational choice can be represented by a simple policy function. Type-e individuals decide to be entrepreneurs if their current wealth $a$ is higher than the threshold wealth $\underline{a}(e)$, where $\underline{a}(e)$ solves:

$$
\pi(\underline{a}(e) ; e, w, r)=w .
$$

For some $e$, there may not exist such an $\underline{a}$. In particular, if $e$ is too low, then $\pi(a ; e, w, r)<w$ for all $a$. In this case, this type of individuals will never become entrepreneurs. Intuitively, individuals of a given ability choose to become entrepreneurs only if they are wealthy enough to overcome the collateral constraint and run their businesses at a profitable scale. Similarly, individuals of a given wealth level choose to become entrepreneurs only if their ability is high enough.

Competitive Equilibrium (Closed Economy) Given $G_{0}(e, a)$, a competitive equilibrium in a closed economy consists of sequences of joint distribution of ability and wealth $\left\{G_{t}(e, a)\right\}_{t=1}^{\infty}$, allocations $\left\{c_{s}\left(e_{t}, a_{t}\right), a_{s+1}\left(e_{t}, a_{t}\right), l_{s}\left(e_{t}, a_{t}\right), k_{s}\left(e_{t}, a_{t}\right)\right\}_{s=t}^{\infty}$ for all $t \geq 0$, and prices $\left\{w_{t}, r_{t}\right\}_{t=0}^{\infty}$ such that:

1. Given $\left\{w_{t}, r_{t}\right\}_{t=0}^{\infty}, e_{t}$, and $a_{t},\left\{c_{s}\left(e_{t}, a_{t}\right), a_{s+1}\left(e_{t}, a_{t}\right), l_{s}\left(e_{t}, a_{t}\right), k_{s}\left(e_{t}, a_{t}\right)\right\}_{s=t}^{\infty}$ solves the agent's problem in (1) for all $t \geq 0$;

2. The labor and capital markets clear at all $t \geq 0$, which by Walras' law implies goods market clearing as well:

$$
\begin{array}{ll}
\sum_{e \in \mathcal{E}} \mu(e)\left[\int_{\underline{a}\left(e, w_{t}, r_{t}\right)}^{\infty} l\left(a ; e, w_{t}, r_{t}\right) G_{t}(d a \mid e)-G_{t}\left(\underline{a}\left(e, w_{t}, r_{t}\right) \mid e\right)\right]=0, & \text { (Labor Market) } \\
\sum_{e \in \mathcal{E}} \mu(e)\left[\int_{\underline{a}\left(e, w_{t}, r_{t}\right)}^{\infty} k\left(a ; e, w_{t}, r_{t}\right) G_{t}(d a \mid e)-\int_{0}^{\infty} a G_{t}(d a \mid e)\right]=0 ; & \text { (Capital Market) }
\end{array}
$$


3. The joint distribution of ability and wealth $\left\{G_{t}(e, a)\right\}_{t=1}^{\infty}$ evolves according to the equilibrium mapping:

$$
G_{t+1}(a \mid e)=\psi \int_{u \leq a} \int_{a^{\prime}(e, v)=u} G_{t}(d v \mid e) d u+(1-\psi) \sum_{\hat{e} \in \mathcal{E}} \mu(\hat{e}) \int_{u \leq a} \int_{a^{\prime}(\hat{e}, v)=u} G_{t}(d v \mid \hat{e}) d u .
$$

A competitive equilibrium for a small open economy is defined in a similar fashion, given a world interest rate $r^{*}$. In this case, the domestic capital rental market and goods market do not need to clear, and the net foreign asset $(N F A)$ equals:

$$
N F A_{t}=\sum_{e \in \mathcal{E}} \mu(e)\left[\int_{0}^{\infty} a G_{t}(d a \mid e)-\int_{\underline{a}\left(e, w_{t}, r^{*}\right)}^{\infty} k\left(a ; e, w_{t}, r^{*}\right) G_{t}(d a \mid e)\right] .
$$

\section{Quantitative Exploration}

The central objective of this paper is to construct a quantitative model of TFP dynamics and capital flows during the process of development - the transition of economies from a steady state with low per-capita income to a steady state with high per-capita income. Following a recent literature emphasizing the role of idiosyncratic distortions (Restuccia and Rogerson, 2008; Guner et al., 2008; Hsieh and Klenow, 2007), we interpret development dynamics as arising from reforms that remove idiosyncratic (non-financial) distortions, while domestic financial market frictions remain. In order to quantify our theory, we need first to choose a set of structural parameters (preferences, technologies, distribution of entrepreneurial ability) that are common across economies. Then we choose a set of structural parameters that are different across economies - parameters governing idiosyncratic distortions and financial frictions. Once all these parameters are chosen, we can use our model to construct the initial condition for the transitions, $G_{0}(e, a)$. This initial condition is a stationary equilibrium of an economy that (i) has idiosyncratic distortions, (ii) is closed to goods and capital flows, and (iii) has a poorly-functioning domestic financial institutions.

One may object to our assumption that different countries are endowed with the same underlying talent distribution. In fact, it would be straightforward to incorporate cross-country differences in the average productivity of potential entrepreneurs and workers by considering human capital and exogenous TFP differences. As the primary mechanism of our model concerns the allocation of resources among heterogeneous producers, however, the main results of our analysis are robust to such relaxation of our heroic assumption. In addition, our model provides a theory of crosscountry differences in the dispersion of productivity among active entrepreneurs, driven by financial frictions and non-financial distortions. It is less obvious how one would model exogenous crosscountry differences in the higher moments of the entrepreneurial talent distribution.

\subsection{Calibration}

We first calibrate the common parameters so that the stationary equilibrium of the distortion-free benchmark economy with perfect credit markets matches the US data on standard macroeconomic 
aggregates, establishment-size distribution and dynamics, and income concentration. We then use data on idiosyncratic distortions to construct the initial steady state for our reform exercises.

\subsubsection{Parameters Common across Economies}

We first describe the parametrization of the model, and then discuss the calibration of the parameters that are common across economies. For the sake of clarity, we choose a parsimonious parametrization that follows as much as possible the standard practices in the literature.

We choose a period utility function of the iso-elastic form:

$$
u(c)=\frac{c^{1-\sigma}-1}{1-\sigma} .
$$

We assume that an entrepreneur with talent $e$ who hires $k$ units of capital and $l$ units of labor produces according to the following production function:

$$
f(e, k, l)=e\left(k^{\alpha} l^{1-\alpha}\right)^{1-\nu}
$$

where $1-\nu$ is known as the span-of-control parameter. Accordingly, $1-\nu$ represents the share of output going to the variable factors. Out of this, fraction $\alpha$ goes to capital, and $1-\alpha$ goes to labor.

The entrepreneurial ability $e$ is assumed to be a truncated and discretized version of a Pareto distribution whose probability density is $\eta e^{-(\eta+1)}$ for $e \geq 1$. Each period, an individual may retain her previous entrepreneurial ability with probability $\psi$. With probability $1-\psi$, she draws a new ability realization from the Pareto distribution given above. Obviously, $\psi$ controls the persistence of ability, while $\eta$ determines the dispersion of ability in the population.

We now need to specify seven parameter values: two technological parameters $\alpha, \nu$, and the depreciation rate $\delta$; two parameters describing the process for ability $\psi$ and $\eta$; the reciprocal of the intertemporal elasticity of substitution $\sigma$ and the subjective discount factor $\beta{ }^{7}$

We let $\sigma=1.5$ following the standard practice. The one-year depreciation rate is set at $\delta=0.06$. We choose $\alpha=0.3$ to match the aggregate share of capital. We are thus left with four parameters $(\nu, \eta, \psi$, and $\beta)$. We calibrate them using four relevant moments in the US data: the employment share of the top decile of establishments; the share of income generated by the top twentieth; the exit rate of establishments; and the real interest rate. To be more specific, we calibrate the perfectcredit benchmark of our model to match these moments from the US, a relatively undistorted economy. ${ }^{8}$

The first column of Table 1 shows the value of these moments in the US data. The largestmeasured by employment - decile of establishments in the US account for 63 per cent of total

\footnotetext{
${ }^{7} \mathrm{As}$ is common in heterogeneous-agent models with incomplete markets, the discount rate must be jointly calibrated with the parameters governing the stochastic income process.

${ }^{8}$ In our model, individuals face uninsured shocks to their entrepreneurial ability. We solve the perfect-credit benchmark in two steps. First, given an aggregate supply of capital, we solve for optimal production decisions, occupation choices, and prices. We then use the wage and entrepreneurial profits coming from the production side of the economy to solve for the saving decisions of individuals facing idiosyncratic income shocks. By aggregating over individuals, we obtain the aggregate supply of capital. A stationary equilibrium with perfect credit markets is a (nested) fixed point of these two problems.
} 


\begin{tabular}{lccl}
\hline & US Data & Model & Parameter \\
\hline Top 10\% Employment & 0.63 & 0.63 & \\
Top 5\% Income & 0.30 & 0.31 & $\eta=4.6, \nu=0.19$ \\
\cline { 3 - 4 } Establishment Exit Rate & 0.10 & 0.10 & $\psi=0.89$ \\
\cline { 3 - 4 } Real Interest Rate & 0.04 & 0.04 & $\beta=0.92$ \\
\hline
\end{tabular}

Table 1: Calibration

employment (as of 2000). We target the income share of the top twentieth of the population (0.3, as of 1998), and an annual job destruction rate of ten per cent (Davis et al., 1996). Finally, as the target interest rate, we pick four per cent per year.

The second column of Table 1 shows the moments simulated from the calibrated model. Even though in the model economy all four moments are jointly determined by the four parameters, each moment is primarily affected by one particular parameter. We briefly discuss the identification and interpretation of some of the parameter values. Given the span-of-control parameter $1-\nu$, the tail parameter of the ability distribution $\eta$ can be inferred from the tail of the distribution of employment. We can then infer $\nu$ from the share of income of the top five per cent of the population. Top earners are mostly entrepreneurs (both in the data and in our model), and $\nu$ controls the share of output going to the entrepreneurial input. These two parameters are calibrated at $\nu=0.19$ and $\eta=4.6$. The parameter $\psi=0.89$ leads to an annual exit rate of ten per cent in the model. Finally, the model requires a discount factor $\beta=0.92$ to match the interest rate of four percent.

\subsubsection{Output Distortions and Financial Frictions}

We model the initial condition for our transition exercises as the joint ability-wealth distribution in a closed-economy stationary equilibrium under financial frictions and non-financial distortions. For the purpose of measurement exercises, these frictions can be thought of as idiosyncratic distortions, or individual-specific taxes/subsidies $\left(\tau_{y i}, \tau_{k i}\right)$, that distort the static profit-maximization problem of an entrepreneur into:

$$
\left(1-\tau_{y i}\right) e_{i}\left(k_{i}^{\alpha} l_{i}^{1-\alpha}\right)^{1-\nu}-w l_{i}-\left(1+\tau_{k i}\right)(\delta+r) k_{i} .
$$

Note that $\tau_{k i}$ is a reduced-form representation of the financial frictions in our model - the collateral constraint $\lambda$ in our model is not individual-specific. ${ }^{9}$ This specification is identical to the framework that Hsieh and Klenow (2007) use to quantify idiosyncratic distortions in Chinese and Indian manufacturing sectors. In particular, they define and measure a geometric average of output and capital distortions for each production unit: $\tau_{i} \equiv\left(1+\tau_{k i}\right)^{(1-\nu) \alpha} /\left(1-\tau_{y i}\right) .{ }^{10}$ More dispersion of $\tau_{i}$

\footnotetext{
${ }^{9}$ In particular, $1+\tau_{k i}=\alpha(1-\nu)\left(1-\tau_{y i}\right) e_{i} k\left(a,\left(1-\tau_{y i}\right) e_{i}\right)^{\alpha(1-\nu)-1} l\left(a,\left(1-\tau_{y i}\right) e_{i}\right)^{(1-\alpha)(1-\nu)}$, where $k\left(a,\left(1-\tau_{y i}\right) e_{i}\right)=$ $\min \left\{\lambda a, k^{u}\left(\left(1-\tau_{y i}\right) e_{i}\right)\right\}$, and $k^{u}(\cdot)$ denotes the unconstrained profit-maximizing level of capital input as a function of an individual's distorted ability. Again, individual financial wealth is denoted by $a$.

${ }^{10} \mathrm{H}$ sieh and Klenow assume monopolistically-competitive firms that use constant returns to scale technologies and face iso-elastic demands. It can be shown that their measured distortions are isomorphic to those in our framework.
} 
translates into lower aggregate TFP and output. They find that idiosyncratic distortions $\left(\tau_{i}\right)$ in Chinese and Indian manufacturing sectors are rampant, with a log-difference between the ninetieth and the tenth percentiles of 1.73-1.87 (compared with 1.04 in the US). In Table 2 we reproduce these moments for China, India and the US.

In the perfect-credit benchmark of our model without non-financial distortions (i.e., $\tau_{y i} \equiv 0$ ), which is calibrated to the US data, measured $\log \tau_{i}$ is zero for all production units indexed by $i$. There are two reasons for omitting non-financial distortions $\left(\tau_{y i}\right)$ in our perfect-credit benchmark and instead targeting the difference in the dispersion of distortions between the US and China/India. First, parts of the measured distortions may be measurement errors that affect the data from China, India and the US in a similar way. Second, the benchmark calibration (Section 3.1.1) is cleaner without $\tau_{y i}$ 's.

\begin{tabular}{lccc}
\hline & $90-10$ & TFP & Wealth Share of Top 5\%e \\
\hline US & 1.04 & $\ldots$ & $\ldots$ \\
China/India & $1.73-1.87$ & $\ldots$ & $\ldots$ \\
\hline$\lambda=1.5, \tau_{y i} \equiv 0$ & 0.82 & 0.81 & 0.47 \\
$\lambda=1.5, \tau_{y i} \neq 0$ & 0.86 & 0.66 & 0.37 \\
\hline
\end{tabular}

Table 2: Measured Distortions. The column ' $90-10$ ' reports the log-difference between the ninetieth and the tenth percentile production units in terms of $\tau_{i}$. The upper panel data on the US and China/India are from Hsieh and Klenow (2007). The lower panel reports corresponding moments from our model. The first row in the lower panel is the case with financial frictions only. The last row is the case with both financial frictions and non-financial distortions. TFP is normalized by its level in the perfect-credit benchmark $(\lambda=+\infty)$ with no idiosyncratic distortions ( $\tau_{y i} \equiv 0$ for all production units). The last column reports the share of wealth held by the top twentieth of the true (undistorted) ability distribution.

We impose a $\tau_{y i}$ process and financial frictions $(\lambda=1.5$, which results in an external finance to GDP ratio of a typical less developed economy, 0.6-0.8) onto our benchmark calibration (Table 1 ), and use our model to compute the stationary equilibrium. ${ }^{11}$ We discipline our choice of $\tau_{y i}$ so that, among the active entrepreneurs in the stationary equilibrium, the log-difference between the ninetieth and the tenth percentiles (in terms of $\tau_{i}$ ) is around 0.8 (the difference between China/India and the US). ${ }^{12}$ Last but not least, we also impose that the subsidies and taxes through $\tau_{y i}$ cancel out across all active establishments, so that the net tax revenue/subsidy is zero. Recall that $\tau_{k i}$ is a mere accounting device and hence does not factor into the tax revenue/subsidy calculation.

One caveat is that the span of control parameter, $1-\nu$, corresponding to Hsieh and Klenow's calibration of the elasticity of substitution is on the low side (close to 0.5). In our economy, idiosyncratic distortions will have a substantially smaller effect on TFP, because of our more conventional choice of $1-\nu=0.81$ (Atkeson and Kehoe, 2005).

${ }^{11}$ We specify a process for distorted entrepreneurial abilities $\tilde{e}=\left(1-\tau_{y}\right) e$. The process for distorted abilities $\tilde{e}$ is described by a probability distribution $\varphi(\tilde{e} \mid e)$, summarizing the probability with which an individual with ability $e \in \mathcal{E}$ is assigned a distorted ability $\tilde{e} \in \tilde{\mathcal{E}}$. The support of the distorted abilities is a transformation of that of the true abilities, $\tilde{\mathcal{E}}=\mathcal{T}(\mathcal{E})$. We assume that the distorted ability and the true ability are equally persistent $(\psi)$, and have the same support.

${ }^{12}$ It turns out that the effects on TFP of the underlying distribution of distortions are not necessarily well captured by a limited set of moments, such as the 90-10 ratio. We choose to complement the information provided by the moments reported in Hsieh and Klenow (2007) with a conservative upper bound for the effect on TFP. 
The second-to-last row of Table 2 corresponds to an economy with financial frictions but no $\tau_{y i}$. The log-difference between the ninetieth and the tenth percentiles of $\tau_{i}$ is 0.82 . In this economy, TFP is only affected by financial frictions, and it is 19 per cent below that of the benchmark economy. The bottom row $\left(\lambda=1.5, \tau_{y i} \neq 0\right)$ of Table 2 is the stationary equilibrium that closely matches our targets. In particular, the TFP of the economy subject to both financial frictions and non-financial distortions is 34 per cent lower than in the benchmark economy. Both output and capital distortions have a similar role in lowering TFP: Financial frictions alone reduce the TFP by 19 per cent, and the output distortions further reduce TFP by additional 15 per cent (again relative to the perfect-credit benchmark level).

In computing the stationary equilibrium, we also obtain the corresponding joint distribution of ability and wealth. The wealth share of the top twentieth of individuals in terms of true ability $(e)$ is 0.37 in the economy with financial frictions and non-financial distortions. This is lower than in the economy with financial frictions only (0.47). With financial frictions, individual wealth determines via the collateral constraint how much capital an entrepreneur can use for production. The lower concentration of wealth (and hence resources) in the hands of the most productive entrepreneurs is a measure of resource misallocation attributable to non-financial distortions $\left(\tau_{y i}\right)$.

The joint distribution of wealth and ability summarized in the bottom row of Table 2 is the initial condition for our transition exercises in Section 3.3. In summary, the pre-reform initial condition is the stationary equilibrium of an economy that (i) has idiosyncratic distortions $\left(\tau_{y i} \neq 0\right.$ ), (ii) is closed to goods and capital flows, and (iii) has poorly-functioning domestic financial markets $(\lambda=1.5)$.

\subsection{Steady State Results: Financial Frictions and the Returns to Saving}

We first report the long-run effects of financial frictions in our model. ${ }^{13}$ In Figure 3, we consider how the output and interest rate of the stationary equilibria respond to changes in the collateral constraint parameter $\lambda$. Recall that a lower $\lambda$ means more financial frictions, with $\lambda=1$ corresponding to zero external financing and $\lambda=+\infty$ to perfect credit markets. For this analysis, the economy is closed, and there is no output distortion $\left(\tau_{y i} \equiv 0\right)$. There is a monotonic relationship between $\lambda$ and the equilibrium ratio of external finance to GDP: The higher $\lambda$, the higher the external finance to GDP ratio. We plot equilibrium output and interest rate against external finance to GDP ratio, instead of $\lambda$ itself. In the figure, we are considering the range of external finance to GDP that is relevant to developing countries (0.1 to 1.58). Our perfect-credit benchmark, for example, has an external finance to GDP ratio exceeding 2.0, which corresponds to the US level.

The left panel shows the effect of the collateral constraint on aggregate output, which is measured relative to its value in the case with $\lambda=7.5$ (external finance to GDP ratio of 1.58 ). Note that financial frictions have a sizable effect on output: As we reduce financial intermediation, output can drop by 27 per cent. Nevertheless, this exercise shows that financial frictions alone are not enough to account for the output gap between developed and less developed economies.

\footnotetext{
${ }^{13}$ See Buera and Shin (2008) and Buera et al. (2009) for more on the long-run effects of financial frictions.
} 

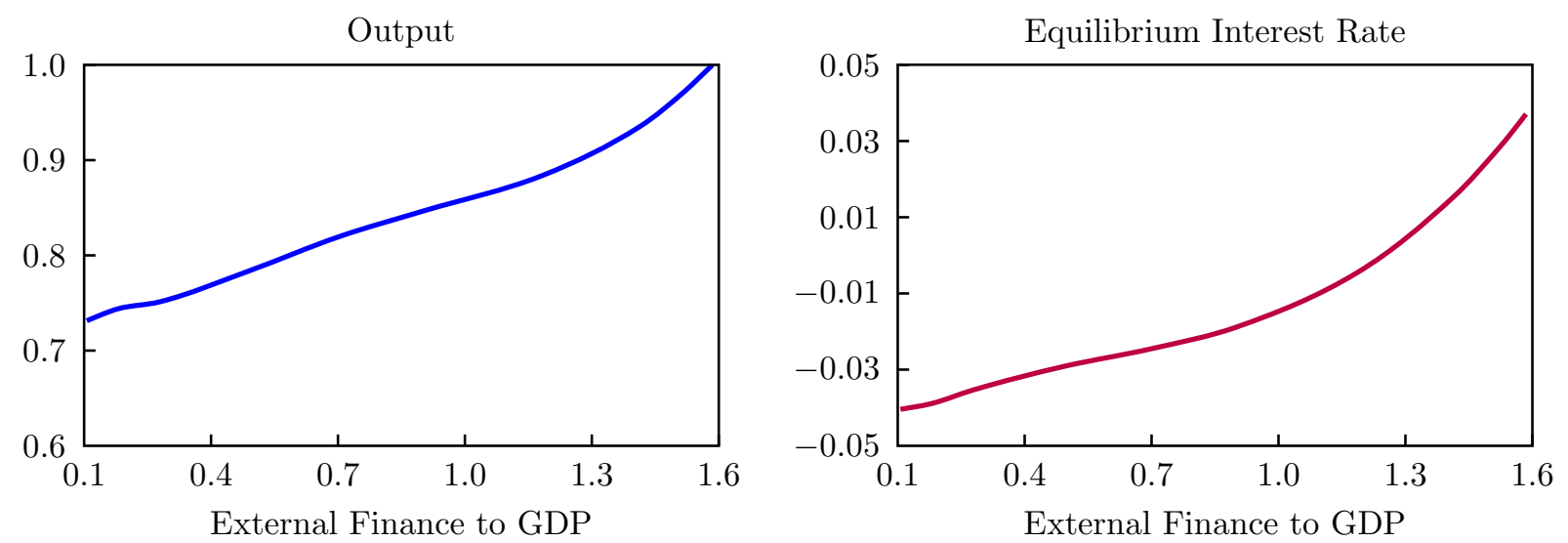

Fig. 3: The Effect of Financial Frictions on Closed-Economy Stationary Equilibria. We generate stationary equilibria corresponding to different degrees of financial frictions $(\lambda)$. These economies are closed, and there are no idiosyncratic non-financial distortions $\left(\tau_{y i} \equiv 0\right)$. The external finance to GDP ratio (horizontal axis) has a monotonic (positive) relationship with $\lambda$. Here $\lambda$ ranges from 1.1 (external finance to GDP of 0.1) to 7.5 (external finance to GDP of 1.58). Output (left panel) is normalized by its level with $\lambda=7.5$.

More important, economies with worse credit markets have lower equilibrium interest rates. The lower interest rate in the general equilibrium follows from entrepreneurs' restricted demand for capital because of tighter collateral constraints, and also from their higher saving rates because of the need for self-financing (a bigger supply of capital, all else equal). This prediction of our model is consistent with empirical findings. Figure 4 plots the time-averaged real returns to saving of a country against its income level. The regression line has a positive slope, consistent with our model prediction that returns to saving in less developed countries with poorly-functioning financial markets are lower than those in developed countries. ${ }^{14}$ This is not surprising given the prevalence of "financial repression" in less developed countries.

From this, we can foresee what will happen if capital is allowed to flow across countries. When a less developed country opens up to international capital markets, the domestic interest rate will rise and be equalized with the world interest rate, which is pinned down by large, rich countries with well-functioning financial markets. At this new, higher interest rate, there is excess supply of domestic capital in the rental market, and this surplus capital will be rented out to overseas production units. This is the main mechanism explored in the literature to explain why capital may flow from less developed to more developed economies. The examples include Gertler and Rogoff (1990), Boyd and Smith (1997), Matsuyama (2005), and Mendoza et al. (2009). Our contribution is to go beyond this result and endogenize the joint transitional dynamics of aggregate productivity and capital flows. To the best of our knowledge, we are the first to do so.

\footnotetext{
${ }^{14}$ The average return is not adjusted for risk. Given the volatility of the real returns to saving in less developed economies, the regression line will tilt steeper, if we look at risk-adjusted returns. Independently of our work, Ohanian and Wright (private communication) obtained similar results. Note that, in our model, if we were to allow for borrowing across periods (i.e. $a<0$ ) subject to the natural borrowing limit, the equilibrium interest rate will have to be positive.
} 


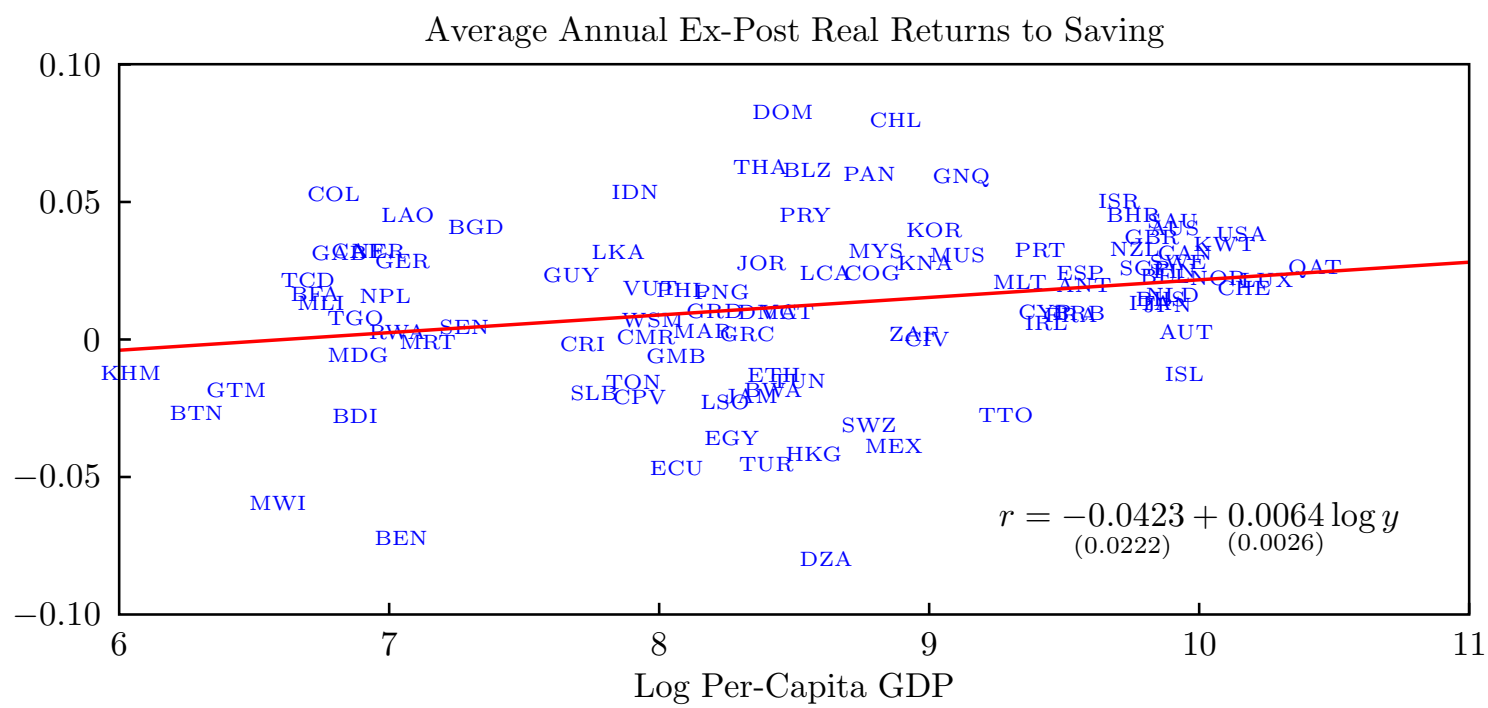

Fig. 4: Returns to Saving across Countries. The data are from the International Financial Statistics (IFS) database. We subtract ex-post inflation rates from nominal deposit rates. When deposit rates are not available, we use returns on government-issued securities. The average over the 1980-95 period is shown for both the real returns to saving and the per-capita GDP. Ex-Soviet countries, other than Russia, are excluded.

\subsection{Post-Reform Transition Dynamics}

In this section, we study the co-movement of TFP and capital flows following large-scale economic reforms and liberalizations. We consider two main exercises. Both will start with a closed economy that is laden with idiosyncratic distortions, in addition to financial frictions, and hence with resource misallocation. The domestic financial market is underdeveloped, with $\lambda=1.5$ to be consistent with the data on external finance in a typical less-developed country (Beck et al., 2000). The construction of this initial condition has been discussed in detail in Section 3.1.2.

Building Intuition: One Reform at a Time Before we begin, we consider two simple exercises to illustrate the effects of different reforms. In our main exercises below, we open the economy to goods and capital flows, precisely when we implement a reform to eliminate idiosyncratic distortions. In the simple exercises here, starting from the same initial condition, we consider first opening up the economy while leaving idiosyncratic distortions intact. We then look at the alternative exercise of eliminating idiosyncratic distortions while leaving the economy closed to goods and capital flows.

In the left panel of Figure 5, we open up the economy to goods and capital flows in year zero, without doing anything about the idiosyncratic distortions. The domestic financial market is left as it was. Capital flows out of the economy, and the net foreign asset position (NFA) jumps up and increases smoothly over time. This result should have been expected based on our discussion in Section 3.2 (right panel, Figure 3). However, without any reform on idiosyncratic distortions, the aggregate productivity (TFP) of the economy barely moves. It actually goes up by six per cent, as the new, higher rental rate of capital shuts down marginal producers, who tend to be incompetent entrepreneurs propped up by subsidies. In addition, the higher TFP also reflects the fact that 
Opening without Eliminating Distortions

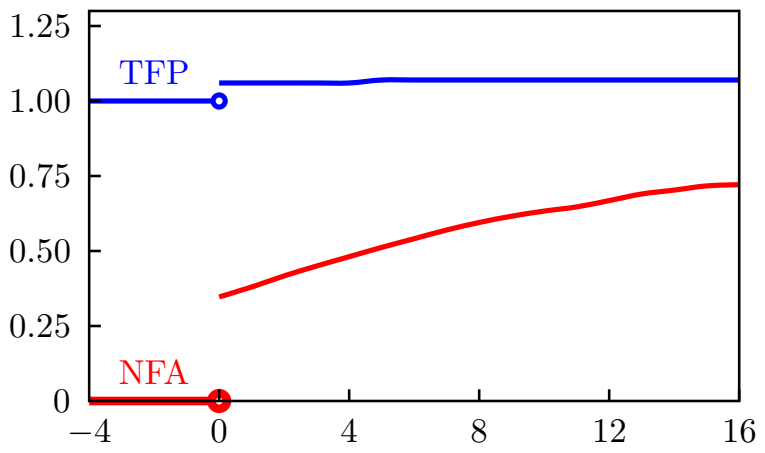

Eliminating Distortions without Opening

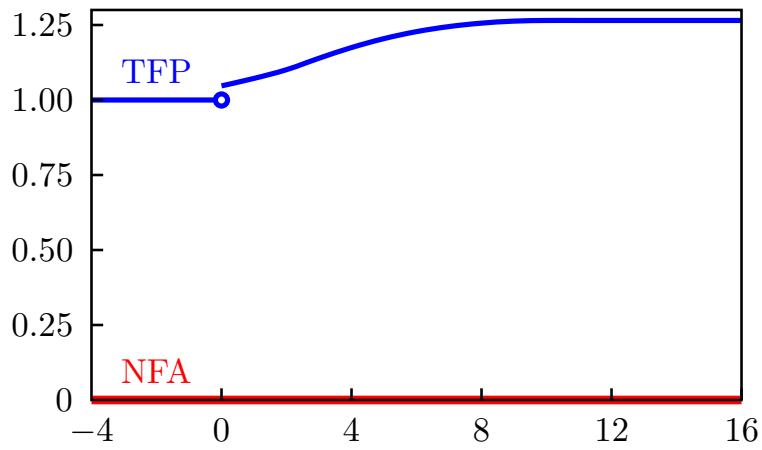

Fig. 5: One Reform at a Time. In the left panel, the economy opens up to the international capital market in year 0 , but no reform is implemented to address either idiosyncratic distortions or domestic financial frictions. The net foreign asset (NFA) is relative to the pre-reform aggregate capital stock $K_{0-}$. TFP is relative to its pre-reform level. In the right panel, a reform is implemented to remove all idiosyncratic distortions, but the economy remains closed and the domestic financial frictions remain intact. The unit of the horizontal axis is years.

productive entrepreneurs can enter and grow faster than before, as they now earn higher returns to their saving. ${ }^{15}$

In the right panel of Figure 5, we consider the opposite: implementing a reform to remove all idiosyncratic distortions, while leaving the economy closed. ${ }^{16}$ Again, the domestic financial market is left as it was. Following the reform, TFP jumps up and gradually increases over time: Over the first ten years following the reform, TFP increases by about 2.5 per cent per year. This reflects more efficient reallocation of resources over time, as productive entrepreneurs save up and enter, while incompetent ones who lose their subsidy exit. However, obviously by assumption, there is no flow of capital in and out of the economy, and the net foreign asset position stays at zero.

The above examples suggest that we should consider an exercise where we eliminate distortions and open up the economy, as our goal is to study the joint dynamics of TFP and capital flows.

Exercise 1: Distortion Removal and Opening Up Here we combine the two reforms considered above. The economic liberalization occurs in year zero. It is unexpected. Once it happens, everyone understands that it is a once-and-for-all change. In this exercise, the liberalization consists of two components. One is the opening up of the economy's capital accounts, and the other is the removal of the idiosyncratic distortions. However, we assume that domestic financial frictions remain intact. We are thinking of financial frictions as arising from enforcement problem, which is a component of broader institutions and is hence more sluggish. The reform experiences of the countries we study in Section 1 are consistent with this sequencing of reforms. Measured in both de jure and de facto sense, domestic financial market reforms lagged behind the removal of

\footnotetext{
${ }^{15}$ However, this last effect is largely unimportant, as it is partly negated by easier self-financing for subsidized incompetent entrepreneurs.

${ }^{16}$ See Buera and Shin (2008) for a detailed analysis of this case. Also, see the appendix of that paper for descriptions of the computational algorithm.
} 
size-dependent or industry-specific taxes and subsidies, as well as capital account liberalizations. ${ }^{17}$

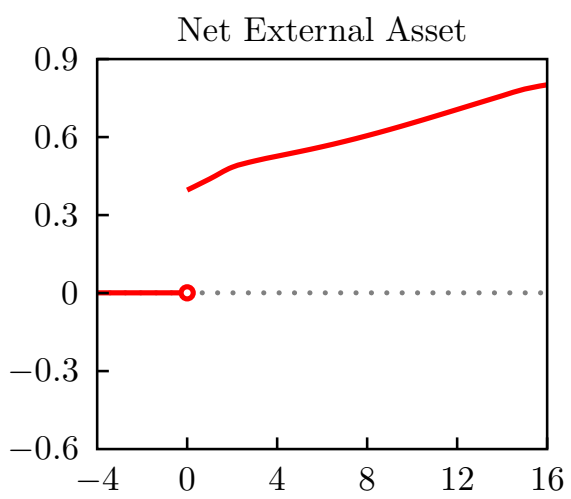

TFP and Average Talent

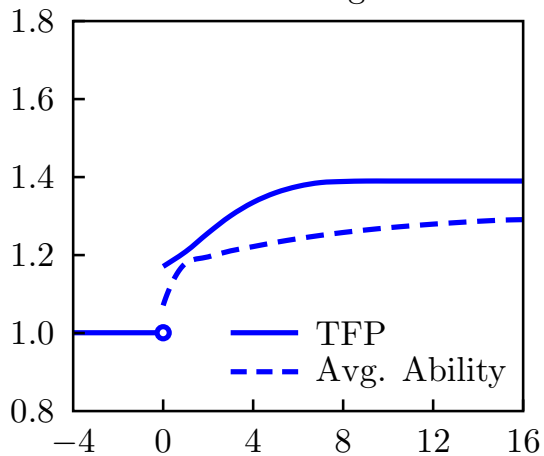

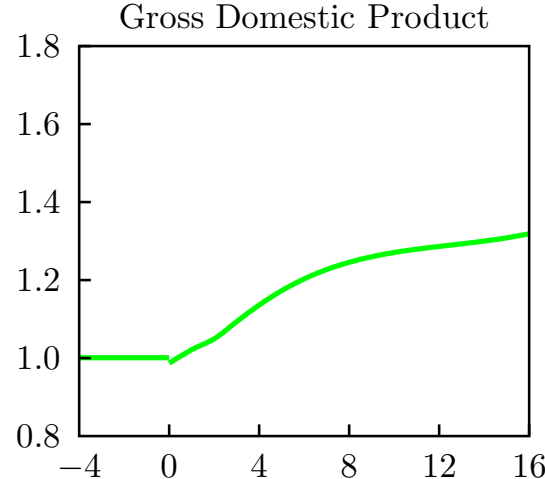

Fig. 6: Transition Dynamics without Domestic Financial Market Reform. In year 0, a reform is implemented to remove all idiosyncratic distortions in the economy. At the same time, the economy opens up to the world capital market. Domestic financial frictions remain intact. In the left panel, net foreign asset positions are measured relative to the pre-reform aggregate capital stock $\left(K_{0_{-}}\right)$. An increase in net foreign asset position implies capital outflows. In the center panel, TFP (solid line) and the average ability of active entrepreneurs (dashed line) are shown. Both quantities are relative to their respective pre-reform level. The right panel plots the GDP series, also relative to its pre-reform level. The unit of the horizontal axis is years.

The result of this liberalization episode is shown in Figure 6. From year 0, as the reform is implemented, resources now get reallocated more efficiently. The increasing TFP reflects this reallocation (solid line, center panel). More efficient reallocation of resources occurs along two margins. First, capital and labor are reallocated among existing entrepreneurs (intensive margin). In addition, more productive entrepreneurs will enter, while previously-subsidized incompetent entrepreneurs will exit (extensive margin). The dashed line in the middle panel shows the average ability/talent of active entrepreneurs. Note that the efficient reallocation along these two margins occur gradually over time (the unit of the horizontal axis is years), as the reallocation is slowed down by domestic financial frictions: It takes time for a talented-but-poor entrepreneur to selffinance the capital needed for operating at a profit-maximizing scale. Both TFP and the average entrepreneurial talent are measured relative to their respective pre-reform levels.

The GDP per capita (right panel) also increases following the reform, largely mirroring the increase in TFP early on (first eight years) and the accumulation of capital later (10 to 20 years after the reform). Per-capita GDP is also measured relative to its pre-reform level.

Notice that capital account liberalization leads to a bigger increase in TFP in the long run, over and beyond the pure effect from the elimination of idiosyncratic distortions (right panel, Figure 5): 38 per cent vs. 26 per cent. With a higher interest rate (owing to the international financial integration) individuals can accumulate assets more quickly for self-financing, and hence collateral constraints inflict less misallocation of productive capital overall. ${ }^{18}$

\footnotetext{
${ }^{17}$ Beim and Calomiris (2001) also document evidence of capital account liberalizations preceding domestic financial market reforms in numerous developing economies.

${ }^{18}$ Note the importance of the joint reforms. For instance, by itself, the liberalization of capital flows leading to a higher interest rate will only generate small TFP gains - six per cent (left panel, Figure 5).
} 
In the left panel, the net foreign asset position jumps up and then goes further up gradually. The NFA is measured relative to the pre-reform aggregate capital stock $\left(K_{0-}\right)$. The increase in the NFA in the beginning is driven by the fall in demand in the domestic capital rental market. Opening up capital accounts implies that the domestic rental rate of capital is equalized to the world level, which is higher. As the rental rate increases, less capital is demanded. At the same time, some of the entrepreneurs who lose their subsidy will begin to exit, further reducing the demand in the domestic capital rental market. However, they are not immediately replaced by truly productive individuals who were previously taxed highly and kept out of entrepreneurial activities. These individuals are not rich enough to overcome the collateral constraints and start production immediately: They have to work as workers and save up enough collateral first. All these factors explain a fall in domestic capital demand, and the surplus capital flows out of the country, increasing the NFA. As the talented entrepreneurs enter and increase their scales of operation over time, domestic demand for capital goes up. This increased demand is partly matched by accumulation of assets (supply of capital) by these entrepreneurs for self-financing purposes - a consequence of domestic financial frictions that still remain. In addition, the higher interest rate induces all individuals to save more, further driving up the net foreign asset position over time. In summary, capital keeps flowing out of the country, while its TFP increases, consistent with the data shown in Figure 2. This is our resolution of the allocation puzzle.

\section{Exercise 2: Distortion Removal, Opening Up, and Domestic Financial Sector Reform}

The difference here is that the large-scale reform in year 0 has one additional component. On top of the capital account liberalization and the removal of idiosyncratic distortions, we will also reform the domestic financial market, increasing its $\lambda$ from 1.5 to 7.5. The choice of $\lambda=7.5$ corresponds to the equilibrium external finance to GDP ratio of 1.58 (Figure 3), which is a level few, if any, developing countries reached before 2000. In this sense, $\lambda=7.5$ represents a very well-functioning financial market by the developing country standard.

The result is shown in Figure 7. The reforms lead to more efficient reallocation of resources, as is reflected on the TFP series. The TFP increases faster and rises higher than in Exercise 1. So do the average entrepreneurial ability and output. In particular, GDP goes up by more than 75 per cent within four years, while in Exercise 1 the corresponding number is 13 per cent. Both Exercises 1 and 2 have the same initial condition, and Figures 6 and 7 have the same scale, facilitating visual comparison. Here the TFP (and GDP as well) increases for two reasons: the removal of idiosyncratic distortions, and the improved domestic financial markets. The latter expedites the reallocation of capital among heterogeneous producers, and facilitates the entry into entrepreneurship of talented individuals. As a result, the TFP grows faster and converges to a higher level than in Exercise 1. So does the GDP.

The net foreign asset position looks starkly different from Figure 6. Initially, opening up capital accounts increases the capital rental rate, and previously-subsidized entrepreneurs exit, reducing the demand in the domestic capital rental market. However, as the collateral constraints are now a 

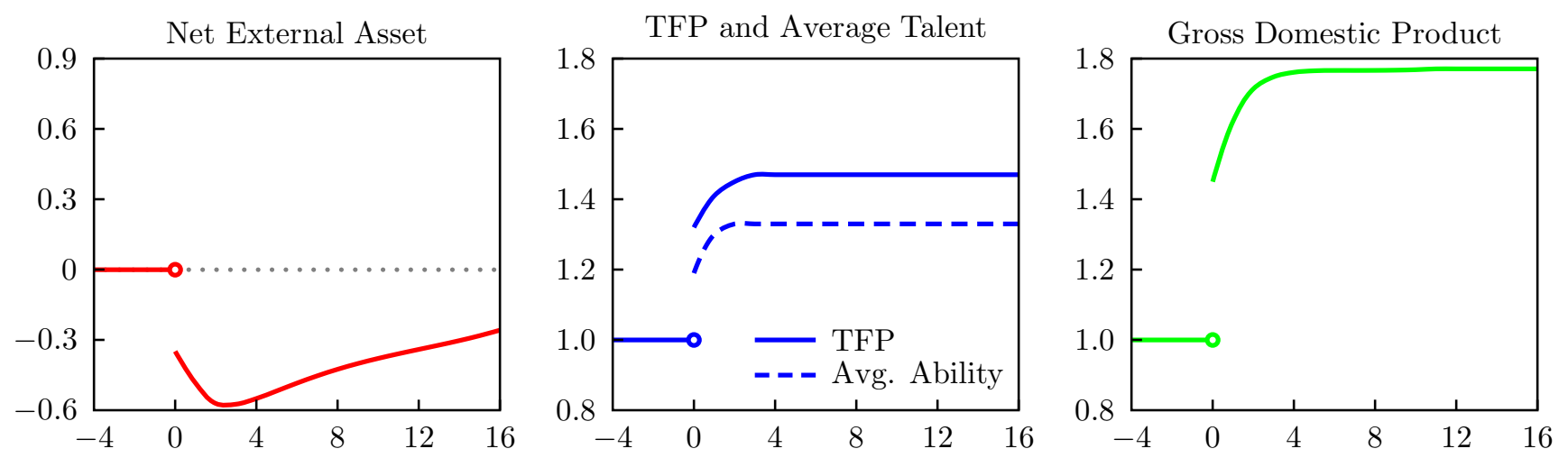

Fig. 7: Transition Dynamics with Domestic Financial Market Reform. In year 0, a reform is implemented to remove all idiosyncratic distortions in the economy. At the same time, the economy opens up to the world capital market. Unlike in Exercise 1, domestic financial frictions are partially eliminated ( $\lambda$ from 1.5 to 7.5$)$. In the left panel, net foreign asset positions are measured relative to the pre-reform aggregate capital stock $\left(K_{0-}\right)$. In the center panel, TFP (solid line) and the average ability of active entrepreneurs (dashed line) are shown. Both quantities are relative to their respective pre-reform level. The right panel plots the GDP series, also relative to its pre-reform level. The unit of the horizontal axis is years.

lot less stringent following the domestic financial market reform, truly-productive individuals can enter entrepreneurship and start production immediately, even if they are poor. This entry more than offsets the fall in the demand for capital by incumbent entrepreneurs and those who exit, and capital flows in from overseas to meet this excess demand. The NFA jumps downward initially. Afterwards, given the rising productivity and the swift increases in domestic demand for capital (because of less strict collateral constraints), capital continues to flow in for the next three years. Note that the entrepreneurs now have weaker self-financing motives given their ability to raise more external financing.

It is informative to compare Exercise 2 with one using the standard neoclassical growth model. In our setup, an economy with perfect domestic credit markets is isomorphic to the neoclassical growth model. If the productivity of the aggregate production function is raised in a neoclassical model, capital will flow into this small open economy and equalize the return to capital with the world level instantaneously. Although our domestic financial market reform does not take our economy all the way to the perfect-credit benchmark, we obtain results that are qualitatively similar.

Empirically, the experiences of Estonia and Thailand can be interpreted as a version of this exercise. Estonia underwent an economy-wide reform in 1992, addressing industrial policies, capital account liberalization, and domestic banking sector reforms (Roland, 2000). In particular, large Swedish banks set up subsidiaries in Estonia and carried out the majority of domestic financial intermediation. As can be seen in Figure 8, Estonia's experience is close to the neoclassical model. To some degree, the Thai reform of 1986 also addressed the domestic financial markets (Townsend, 2006). In particular, the fraction of bank loans forcefully channeled to the government dropped sharply. The ensuing TFP and NFA series are consistent with our results in Figure 7, although the latter phases of the Thai transition are muddled by the 1997 crisis. 

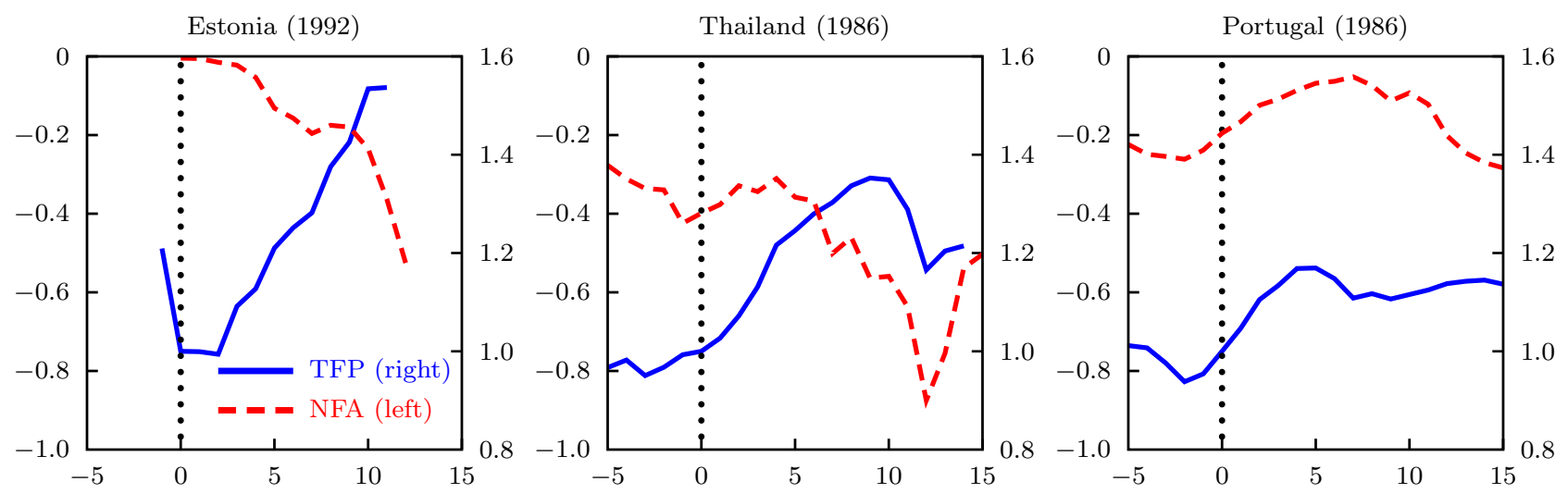

Fig. 8: TFP and Net Foreign Asset Position. Year 0 on the horizontal axis is the year of reform implementation, which is shown in parentheses next to the country name. Net foreign asset position as a fraction of PPP GDP is measured on the left scale, and aggregate TFP can be read off the right scale. TFP is normalized by its value in year 0 . The unit of the horizontal axis is years.

Castro and Clementi (2009) also document the large-scale reform in Portugal as it joined the European Union in 1986. In addition to reducing idiosyncratic taxes and subsidies, Portugal rewrote its century-old commercial code to enhance investor protection. Castro and Clementi show that capital flowed into Portugal, in response to the improved investor protection. The timeseries evidence in Figure 8 is less clear-cut: TFP increased the most during the five-year period immediately following the reform, while capital inflow begins in earnest seven years after the reform. Such observed post-reform dynamics can be reconciled with our model predictions if the domestic financial market reform is implemented piecemeal over several years.

\subsection{Welfare Consequence of Capital Account Liberalization}

While economists readily agree on the merits of removing idiosyncratic distortions and reforming domestic financial markets, there seems to be less certainty regarding the benefits of opening up to international capital flows. Our framework can be used to assess the welfare gains from capital account liberalization. In most studies in the literature, capital account liberalization improves welfare, but the magnitude is rather small. ${ }^{19}$

Here we focus on the interaction of capital account liberalization with other reforms. This is a very relevant question, as capital account liberalizations of developing countries were typically accompanied by other reforms that removed distortions in these economies. We here analyze the welfare gains from capital account liberalization by comparing the economic outcomes of removing idiosyncratic distortions while opening up (Exercise 1) with those of removing idiosyncratic distortions while remaining closed to capital flows. The latter has already been analyzed in Section 3.3,

\footnotetext{
${ }^{19}$ See Gourinchas and Jeanne (2006) and the references therein. Unlike most work in the literature that assumes a small economy populated by a representative agent, our model has heterogeneous individuals within an economy and can address differential effects of capital flows on these individuals. Aoki et al. (2007, 2009) and Mendoza et al. (2009) also provide welfare analyses with heterogeneous-agent models.
} 
as one of the simple exercises (right panel, Figure 5). We report the welfare differences between these two exercises.

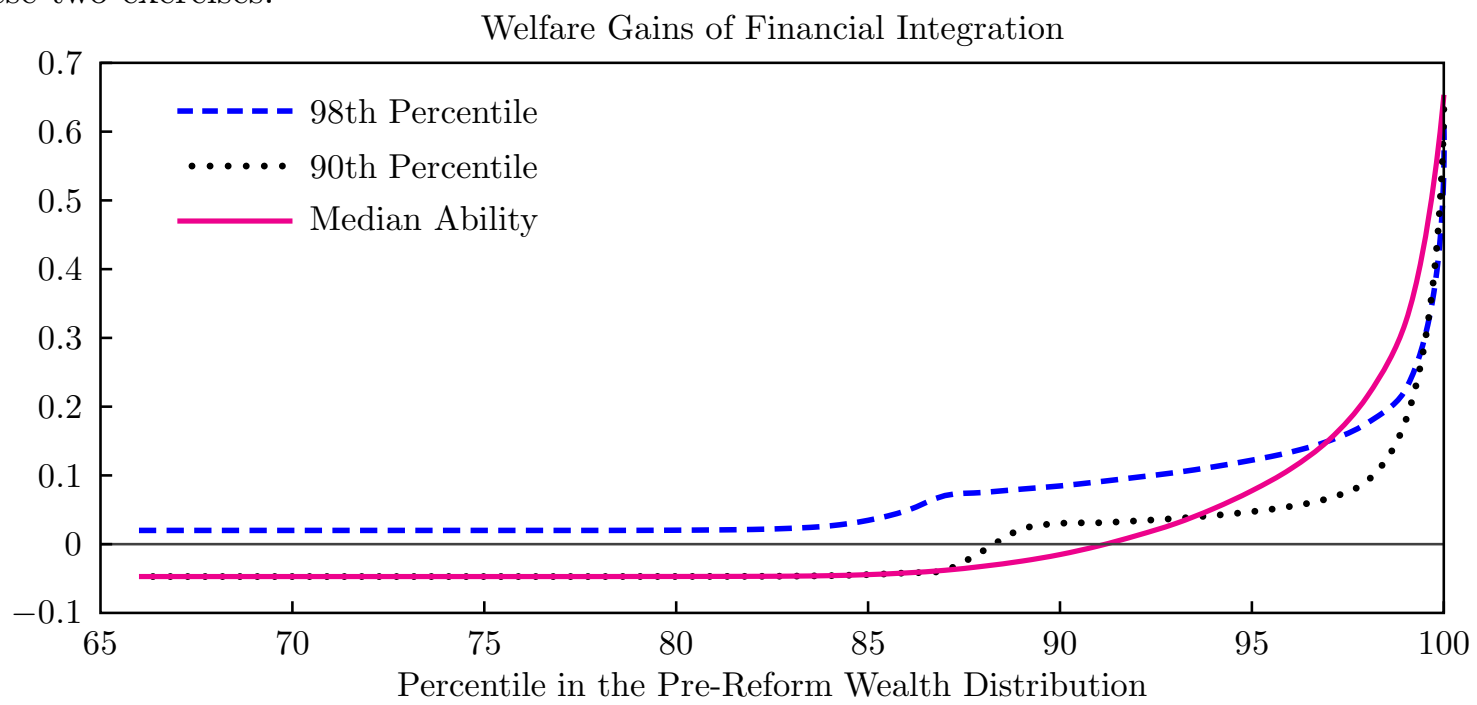

Fig. 9: Welfare Gains from Capital Account Liberalization. The horizontal axis is the percentile in the prereform (unconditional) wealth distribution. Each curve corresponds to different ability level. The vertical axis is welfare gains in units of relative increase in permanent consumption. A positive number implies a particular individual of a given ability and wealth at the time of the reform is better off with concurrent capital account liberalization. A negative number, on the other hand, indicates that the individual is better off when the removal of idiosyncratic distortions is done in a closed-economy environment.

On the horizontal axis of Figure 9, individuals are sorted according to their wealth prior to the reform. Each curve corresponds to individuals with different ability. For example, the dashed line is for those individuals who are more talented than all but two per cent of the population. The vertical axis measures the welfare difference in units of permanent consumption. A positive number means that this particular type of individual - where type is defined as one's wealth level and ability at the time of the reform-prefers the removal of idiosyncratic distortions to be accompanied by opening up of capital accounts. Similarly, a negative number means that the individual prefers the removal of idiosyncratic distortions to be done in a closed-economy environment.

We find that not all individuals benefit from concurrent capital account liberalization. Obviously, the wealthy directly benefit from capital account liberalization, which instantaneously give them a higher return - the world interest rate - on their financial assets. High-ability individuals, who will choose to be entrepreneurs and likely be wealthy, are better off when the economy also opens up. Even the talented-but-poor individuals, because they get rich over time, benefit from the higher interest rate - the left tail of the dashed line lies above zero. On the other hand, low-ability individuals, who will choose to be workers, are better off when the economy remains closed, unless they start out very wealthy (solid line). With capital account liberalization, capital flows out of the country following the reform. Holding other things equal, this implies less capital per worker for domestic production, and the wage is lower than in the closed-economy transition, albeit temporarily. Wage eventually rises to a higher level with capital account liberalization, but the lower 
wage along the transition prevails on the overall welfare of low-ability individuals.

Given that the very wealthy and entrepreneurs are but a small fraction of the population, the vast majority would prefer the elimination of idiosyncratic distortions to be carried out with capital account controls in place.

\section{Concluding Remarks}

We show in our quantitative framework that, following a reform that eliminates idiosyncratic distortions and liberalizes capital flows, there will be a gradual rise in TFP accompanied by capital outflows. The rising TFP is the consequence of the more efficient reallocation of capital and talent, a process slowed down by frictions in domestic financial markets. Capital outflows are driven by the rise in domestic saving in response to a higher return, and by the sluggish response of domestic investment to the higher productivity, the latter being another consequence of the frictions in domestic financial markets. From our exercises, we conclude that it is important to understand the workings of domestic financial markets first if one wanted to evaluate the consequences of capital account liberalization. Indeed, opening up capital accounts may well have adverse welfare consequences for the majority of the population in economies with underdeveloped domestic financial markets.

Our analysis abstracts from different types of capital flows, e.g., debt contracts vs. foreign direct investment, which could exhibit different dynamics. For instance, in recent years, we have observed developing countries accumulating debt claims on foreigners while receiving foreign direct investment. We conjecture that an extension of our model that allows for the joint mobility of capital and entrepreneurial talents will account for such gross flow patterns. As in the current paper, we would observe capital in the form of debt contracts flow out of economies with underdeveloped domestic financial markets. At the same time, there will be wealthy foreign entrepreneurs who can bring in their own capital or collateral into such countries to take advantage of their lower factor prices. Such an extension will also enable us to study the flow of talented-but-undercapitalized entrepreneurs who will migrate into countries with more developed financial markets, a phenomenon resembling what is often referred to as "brain drain." 


\section{Appendix: Notes on Economic Reforms}

We briefly describe the six large reform episodes that took place during the 1980s and the 1990s. We emphasize the three components of reforms we use in our model: reduction of idiosyncratic distortions, capital account liberalization, and domestic financial market reform.

Chile, 1985 Following the debt and banking crisis of the early 1980s, in 1985 the Chilean government started a round of reforms (Bosworth et al., 1994). These included the privatization of state-owned enterprises and firms taken over during the 1982 financial collapse, and the reversal of protective measures imposed during the crisis. This wave of reforms not only reinforced the broad movement toward a more market-oriented allocation of resources that had started in the mid 1970s, but also remedied some shortcomings of the earlier reforms - e.g., the earlier process of privatization allowed the formation of business conglomerates through the sale of state-owned assets, which were purchased with financing provided by the state with funds obtained by abusing the implicit bank deposit insurance. The reforms of 1985 proved to be longer-lasting. We interpreted these series of reforms as more credible efforts at removing/reducing idiosyncratic distortions in the context of our model.

Controls on capital outflows that had been imposed in 1982 were removed in 1985, although restrictions on short-term capital inflows remained.

At the time of the 1985 reform, the domestic financial markets were still reeling from the financial crisis of 1982. While the financial system developed significantly in the following decade, financial intermediation remained relatively limited through the mid 1990s.

India, 1991 Following a balance of payment crisis, in 1991 India embarked on a broad set of reforms (Kochhar et al., 2006). These reforms included the abolition of industrial licensing and the narrowing of the scope of public sector monopolies to a much smaller number of industries; trade liberalization which included elimination of import licensing and progressive reduction of non-tariff barriers; the liberalization of investment in important services, such as telecommunications; and limited financial sector reforms.

Deregulation of capital flows began in 1991, with the liberalization of inward foreign direct and portfolio investment. Exchange rates were unified in 1993, and current account convertibility was achieved by 1994 .

Gradual domestic financial sector reforms started in the mid 1990s, including the removal of controls on capital issues, and freer entry for domestic and foreign private banks. However, credit control remained throughout the 1990s.

Israel, 1985 In 1985 a successful stabilization plan was put into place. As a consequence of budget adjustments and subsequent reforms, the principal markets (capital, foreign exchange, and labor) underwent important changes (Ben-Bassat, 2002). Government interventions in production factor markets and in finances were significantly reduced. The share of government expenditure in 
the GDP declined by 20 percentage points in the first ten years of the reform. More important, the composition of the budget changed from an emphasis on subsidies to "priority" industries and regions, into broader investment in infrastructure. Earlier protectionist tendencies were slowly reverted. In 1985 a free-trade agreement with the US was signed, and by 1990 all non-tariff barriers on imports from "third countries" were abolished and replaced with uniform tariffs. In 1992 a process of lowering these tariffs started.

Controls on capital flows that had been imposed in 1970 began to be reversed in 1987, and the liberalization was more or less completed by 1998. The remaining restrictions pertain to overseas investment by institutional investors and forward transactions.

Distortions to domestic financial markets remained significant until the mid 1990s. Directed credit, regulated interest rate, public ownership of major banks lasted until the mid 1990s.

Korea, 1982 In the second half of the 1970s, the Korean government embarked on a largescale program subsidizing heavy and chemical industries. This was a form of import substitution, and the beneficiaries were steel, petrochemical, nonferrous metals, shipbuilding, electronics, and machinery industries. This experiment ceased and began to be reversed in 1981 (Leipziger, 1997). The failed industrial policy led the government to delegate the role of investment planning to the private sector. Entry of small and medium-sized firms was deregulated from the early 1980s. The sector/industry-specific taxes were replaced by flat-rate value-added taxes in the late 1970s.

Controls on capital flows were eased first in 1979 (inward), then in 1982 (inward), and then again in 1985 (inward and outward).

Rampant distortions of the financial markets remained until the mid 1990s. Directed lending and regulated interest rates - often thought of as the legacy or the "scar" from the industrial policies of the 1970s - were phased out beginning in 1995 to join the OECD, and in 1998 to meet the IMF conditionality in the aftermath of the East Asian financial crisis.

Mauritius, 1981 Starting with the negotiation of a structural adjustment loan with the World Bank in 1980, a process of reform began that progressively removed various distortions (Gulhati and Nallari, 1990; Dabee and Greenaway, 2001). The theme of the reforms was to move away from a focus on import substitution, which accounted for 80 per cent of manufacturing investment during 1978-81. These reforms included the elimination of price controls, quantity restrictions on imports, and export taxes on sugar. Also included was a gradual reduction of tariffs. As part of these reforms, the government eliminated the differential tax treatment for companies under various special regimes, e.g., export promotion zones and import substitution regimes. Especially in the sugar industry (a major player well into the 1980s), most size-dependent policies were abandoned, leading to consolidations and productivity gains.

Capital account liberalization began in 1981, although it was a gradual process. Exchange rates were unpegged and managed-floated since 1983.

Domestic financial market reforms began towards the end of the 1980s, with interest rate 
liberalization in 1988. However, pricing and allocation of funds were heavily influenced by the central bank well into the late 1990s. The government's share of domestic commercial bank credit remained at 30-35 per cent until the late 1980s, and then dropped to 25 per cent by the mid 1990s.

Taiwan, 1982 Much like Korea during the mid 1970s, Taiwan's response to the first oil shock in 1974 was to increase the government's involvement in the economy. The government increased spending on infrastructure (railways, roads, and airports) and implemented policies to replace imported intermediate capital goods with domestically-produced materials. The beneficiaries of such import-substitution policies were petrochemical, machinery, and steel industries. At the same time, trade barriers went up, reversing the decades-long trend of trade liberalization. With their eighth four-year plan (1982-86), the emphasis of the economic policy fell again on liberalization and internationalization, removing many of the industrial policies of the late 1970s (Leipziger, 1997).

Foreign exchange rate and capital account liberalizations took place during the mid 1980s.

Throughout the second half of the twentieth century, domestic financial markets served as instruments for the government's industrial policy. Domestic financial market liberalization started in 1989, with controls on bank loan/deposit rates abolished. New entries into the banking sector were not allowed until 1992-95. Financial markets were still tightly regulated even in the late 1990s, although privatization of some financial institutions and more liberalization began in 1994-95. 


\section{References}

Aoki, K., G. Benigno, And N. Kiyotaki (2007): "Capital Flows and Asset Prices," Manuscript, London School of Economics.

- (2009): "Adjusting to Capital Account Liberalisation," Manuscript, London School of Economics.

Atkeson, A. And P. J. Kehoe (2005): "Modeling and Measuring Organization Capital," Journal of Political Economy, 113, 1026-1053.

Beck, T., A. DemirgüÇ-Kunt, And R. Levine (2000): "A New Database on the Structure and Development of the Financial Sector," World Bank Economic Review, 14, 597-605.

Beim, D. O. And C. W. Calomiris (2001): Emerging Financial Markets, New York: McGrawHill.

Ben-Bassat, A. (2002): The Israeli Economy, 1985-1998: From Government Intervention to Market Economics, Cambridge, MA: MIT Press.

Bernanke, B. S., M. Gertler, and S. Gilchrist (1999): "The Financial Accelerator in a Quantitative Business Cycle Framework," in Handbook of Macroeconomics, ed. by J. B. Taylor and M. Woodford, Amsterdam: North Holland, vol. 1C, 1341-1393.

Bernanke, B. S. and R. S. Gürkaynak (2001): "Is Growth Exogenous? Taking Mankiw, Romer and Weil Seriously," in NBER Macroeconomics Annual, ed. by B. S. Bernanke and K. Rogoff, Cambridge, MA: MIT Press, 11-57.

Bosworth, B. P., R. Dornbusch, And R. Labán (1994): The Chilean Economy: Policy Lessons and Challenges, Washington, DC: The Brookings Institution.

Boyd, J. H. And B. D. Smith (1997): "Capital Market Imperfections, International Credit Markets, and Nonconvergence," Journal of Economic Theory, 73, 335-364.

Buera, F. J., J. P. Kaboski, And Y. Shin (2009): "Finance and Development: A Tale of Two Sectors," Working Paper 14914, National Bureau of Economic Research.

Buera, F. J. AND Y. Shin (2008): "Financial Frictions and the Persistence of History: A Quantitative Exploration," Manuscript, Washington University in St. Louis.

Caballero, R. J., E. Farhi, and P.-O. Gourinchas (2008): "An Equilibrium Model of 'Global Imbalances' and Low Interest Rates," American Economic Review, 98, 358-393.

Camdessus, M. (1999): Second Generation Reforms: Reflections and New Challenges, available on the internet at http://www.imf.org/external/np/speeches/1999/110899.HTM. 
Carroll, C. D., J. Overland, And D. N. Weil (2000): "Saving and Growth with Habit Formation," American Economic Review, 90, 341-355.

Caselli, F. And J. Feyrer (2007): "The Marginal Product of Capital," Quarterly Journal of Economics, 122, 535-568.

Castro, R. And G. L. Clementi (2009): "The Economic Effects of Improving Investor Rights in Portugal," Portuguese Economic Journal, Forthcoming.

Castro, R., G. L. Clementi, and G. MacDonald (2004): "Investor Protection, Optimal Incentives, and Economic Growth," Quarterly Journal of Economics, 119, 1131-1175.

Dabee, R. And D. Greenaway (2001): The Mauritian Economy, New York: Palgrave.

Davis, S. J., J. C. Haltiwanger, And S. Schuh (1996): Job Creation and Destruction, Cambridge, MA: MIT Press.

Dommen, E. And B. Dommen (1999): Mauritius, an Island of Success: A Retrospective Study 1960-93, Oxford: James Currey.

Evans, D. S. And B. Jovanovic (1989): "An Estimated Model of Entrepreneurial Choice under Liquidity Constraints," Journal of Political Economy, 97, 808-827.

Gertler, M. And K. Rogoff (1990): "North-South Lending and Endogenous Domestic Capital Market Inefficiencies," Journal of Monetary Economics, 26, 245-266.

Gourinchas, P.-O. And O. Jeanne (2006): "The Elusive Gains from International Financial Integration," Review of Economic Studies, 73, 715-741.

(2007): "Capital Flows to Developing Countries: The Allocation Puzzle," Working Paper 13602, National Bureau of Economic Research.

Gulhati, R. And R. NAllari (1990): Successful Stabilization and Recovery in Mauritius, Washington, DC: World Bank.

Guner, N., G. Ventura, And Y. Xu (2008): "Macroeconomic Implications of Size-Dependent Policies," Review of Economic Dynamics, 11, 721-744.

Hopenhayn, H. A. And R. Rogerson (1993): "Job Turnover and Policy Evaluation: A General Equilibrium Analysis," Journal of Political Economy, 101, 915-938.

Hsieh, C.-T. And P. Klenow (2007): "Misallocation and Manufacturing TFP in China and India," Manuscript, Stanford University.

Kaminsky, G. L. And S. L. Schmukler (2008): "Short-Run Pain, Long-Run Gain: Financial Liberalization and Stock Market Cycles," Review of Finance, 12, 253-292. 
Kiyotaki, N. And J. Moore (1997): "Credit Cycles," Journal of Political Economy, 105, 211248.

Kochhar, K., U. Kumar, R. Rajan, A. Subramanian, and I. Tokatlidis (2006): "India's Pattern of Development: What Happened, What Follows?" Journal of Monetary Economics, 53, 981-1019.

Lagos, R. (2006): “A Model of TFP," Review of Economic Studies, 73, 983-1007.

Lane, P. R. And G. M. Milesi-Ferretti (2007): "External Wealth of Nations Mark II: Revised and Extended Estimates of Foreign Assets and Liabilities, 1970-2004," Journal of International Economics, 73, 223-250.

Leipziger, D. M. (1997): Lessons from East Asia, Ann Arbor, MI: University of Michigan Press.

Lucas, JR., R. E. (1990): "Why Doesn't Capital Flow from Rich to Poor Countries?" American Economic Review, 80, 92-96.

Matsuyama, K. (2005): "Credit Market Imperfections and Patterns of International Trade and Capital Flows," Journal of the European Economic Association, 3, 714-723.

Mendoza, E. G., V. Quadrini, And J.-V. Ríos-Rull (2009): "Financial Integration, Financial Deepness and Global Imbalances," Journal of Political Economy, 117, 371-416.

Mishkin, F. S. (2003): "Financial Policies and the Prevention of Financial Crises in Emerging Market Countries," in Economic and Financial Crises in Emerging Market Countries, ed. by M. Feldstein, Chicago: University of Chicago Press, 90-130.

Prasad, E. S., R. G. Rajan, And A. Subramanian (2007): "Foreign Capital and Economic Growth," Brookings Papers on Economic Activity, 38, 153-230.

Restuccia, D. And R. Rogerson (2008): "Policy Distortions and Aggregate Productivity with Heterogeneous Establishments," Review of Economic Dynamics, 11, 707-720.

Roland, G. (2000): Transition and Economics: Politics, Markets, and Firms, Cambridge: MIT Press.

SANDRI, D. (2009): "Growth and Capital Flows with Risky Entrepreneurship," Manuscript, International Monetary Fund.

Song, Z., K. Storesletten, And F. Zilibotti (2009): "Growing like China," Manuscript, Fudan University.

Stulz, R. M. (2005): "The Limits of Financial Globalization," Journal of Finance, 60, 1595-1638.

Townsend, R. M. (2006): "The Thai Economy: Growth, Inequality, Poverty and the Evaluation of Financial Systems," Manuscript, University of Chicago. 